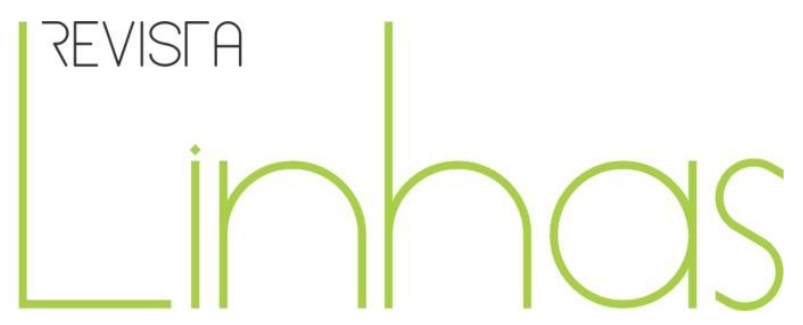

\title{
A escola brasileira representada em duas obras ficcionais no final do século XIX e início do século XX
}

\section{Resumo}

A nossa experiência escolar passa por algumas "imagens literárias" presentes em narrativas de ficção produzidas na passagem do século XIX ao século XX. A educação, na história do Brasil, está representada em dois momentos: a primeira, a experiência escolar vivida por um personagem numa cidade rural do Maranhão e depois na capital da Corte, na segunda metade do século XIX. A segunda, uma sátira social apresentada numa crônica sobre as unidades de ensino na cidade do Rio de Janeiro, na primeira fase da nossa república. Para o desenvolvimento deste estudo foram usadas como opções de fontes duas obras da literatura nacional: o romance Casa de Pensão, do escritor maranhense Aluísio Azevedo (1857-1913), publicado na década de 1880 e a coletânea Os Bruzundangas, do escritor carioca Lima Barreto (1881-1922), publicada na década de 1920. Em qual direção caminhava a educação escolar brasileira no final do século XIX e início do século XX? Naquele contexto, o debate sobre o papel social da educação, partindo das matrizes do pensamento europeu e norte-americano, pulverizava o ideário intelectual brasileiro. A análise de tais textos permitiu a extração de representações sobre cada experiência escolar. A relevância deste estudo está em apresentar o lugar da escola, conforme as narrativas, no projeto de sociedade brasileira que se pretendia republicana.

Palavras-chave: Educação - História - Brasil; Escolas - Brasil; Casa De Pensão; Coletânea Os Bruzundangas.
Francisco Ari Andrade

Universidade Federal do Ceará UFC - CE/Brasil

andrade.ari@hotmail.com

\section{Para citar este artigo:}

ANDRADE, Francisco Ari. A escola brasileira representada em duas obras ficcionais no final do século XIX e início do século XX. Revista Linhas. Florianópolis, v. 17, n. 35, p. 241-269, set./dez. 2016. 


\title{
The brazilian school represented in two fictions works in finally of century XIX and start of century $\mathrm{XX}$
}

\begin{abstract}
In the try of recovers a history pass of education scenery is put in relief literary images about the school in Brazil. The education in two moments verifieds in two fictions narratives. Education in the history of Brazil, is represented in two stages: The first contrast the experience in a school lived for a personage at rural city of Maranhão and letter in the capital of court, in the second mean of century XIX.The second, a social satire presented in chronicle about the units of education at Rio de Janeiro city, in the first period of our republic. For to development of this study, used as option of source two works of national literature: the romance Pension House (Casa de Pensão, in Portuguese) a romance written by Aluísio Azevedo (1857-1913), from the Brazilian state of Maranhão, and published in the 1880's; and the compilation Bruzundangas (Os Bruzundangas, in Portuguese), a collection of books written by Lima Barreto (18811922), from Rio de Janeiro, and published in the 1920's. What direction walked the school Brazilian education in finally of century XIX and start of century XX? That context, the debate about the social paper in education, starting of the European and north American headquarters, spraying the intellectual ideal Brazilian. The analyses of the texts allowed the extraction of representations about each school experiences. The relevance of this study it is in present the school place, according of each narrative, in the project of Brazilian society that project that republican.
\end{abstract}

Keywords: Education - History - Brazil; Schools - Brazil Pension House; Compilation Os Bruzundangas. 


\section{Introdução}

O presente artigo destaca a representação escolar na passagem do século XIX para o século XX. Numa tentativa de remir recortes do cenário educacional brasileiro, são postas em relevo algumas "imagens literárias" sobre a escola no Brasil em dois momentos de duas narrativas ficcionais: a primeira, a experiência escolar vivida por um personagem numa cidade rural do Maranhão provincial e depois na capital da Corte, em meados do século XIX; a segunda, uma sátira social apresentada numa crônica sobre a realidade do ensino brasileiro, no começo do século $X X$, tendo por referência também a cidade do Rio de Janeiro.

Para o desenvolvimento deste estudo foram usadas, como opções de fontes, duas obras da literatura nacional: o romance Casa de Pensão, do escritor maranhense Aluísio Azevedo (1857-1913), publicado na década de 1880 e a coletânea Os Bruzudangas, do escritor carioca Lima Barreto (1881-1922), publicada na década de 1920.

Na análise de tais obras, na perspectiva da pesquisa social, foi possível evidenciar a rotina escolar de cada período, sua dinâmica pedagógica, suas contradições, a forma como os alunos, representados pelos personagens, expressavam sentimentos e sentidos em relação à escola - aos mestres, às lições, aos exames, às arguições, às preleções, aos livros -, bem como suas aspirações sociais a partir do ingresso em um curso superior brasileiro.

As referidas obras são consideradas clássicas na plêiade de autores da literatura de ficção brasileira. Sabe-se que, desde as primeiras edições até hoje, tais obras passaram por ajustes, na maioria das vezes se adequando às reformas ortográficas, sendo acrescentados prefácios e notas de esclarecimentos. Dentre as opções impressas à disposição da comunidade, porque compõem o rol de leituras sugeridas como paradidáticos nas séries do ensino médio nacional, coube a escolha das versões digitais disponíveis nas plataformas virtuais de domínio público.

Muito oportuna passa a ser a utilização da literatura de ficção como fonte importante para se perceber, por meio da verossimilhança, a fotografia social de uma época e, a partir de tal percepção, traçar um recorte histórico composto por meio das 
“imagens literárias" sobre a escola, que se aproxime de uma leitura crítica da educação nacional naqueles períodos.

Em qual direção caminhava a educação escolar brasileira no final do século XIX e início do século XX? Para uma sociedade do progresso ou permaneceria presa ao modelo de sociedade agrária, simbolizado como atraso? Qual o lugar da escola no projeto republicano brasileiro, na passagem do século XIX para o século XX? Quais imagens sobre a escola são apresentadas nas narrativas literárias dos personagens circunscritos em cada obra? Quais os sentidos atribuídos pelos personagens à escola e aos professores? Eis as questões ponto de partida para esse estudo.

A opção pelas obras em destaque da literatura ficcional brasileira se deve ao fato delas trazerem em suas narrativas passagens que denunciam o modelo de educação que se tinha na virada do século XIX para o século XX, no afã de criar um projeto nacional. Tal produção bibliográfica oferece um campo de possibilidades à pesquisa histórica porque encerra crônicas sociais numa dimensão crítico-pedagógica. Por meio da análise de tais narrativas foi possível a recomposição de cenários que denunciavam as contradições de um país que se lançava à órbita republicana. Mesmo tratando-se de uma construção estética, o uso de obras literárias ficcionais como fonte na criação historiadora ganha fôlego, pautado na perseguição do verossímil, do plausível, como "um esqueleto de verdade encarnado na poesia" (NAVA, 1999, p. 58). ${ }^{1}$

Num primeiro momento, o termo "representação" é tomado de empréstimo de Serge Moscovi (1978, p. 25), ao considerar "a organização de imagens, linguagens, porque ela realça e simboliza atos e situações" que norteiam o entendimento acerca da concepção de alguma coisa, de algum objeto, ou de algum sujeito. Na composição desse estudo, no entanto, tomou-se para análise das obras o termo "imagem literária”, trazido à baila por Pinto Neto (2001, p. 18), sempre que, nos textos ficcionais destacados neste artigo, sobressaírem-se construções mentais sobre o objeto eleito, a escola e que venha a despertar a atenção do leitor.

\footnotetext{
1 Sobre a questão é oportuna, também, a apreciação do trabalho de Juliana Ferreira de Melo intitulado Modos e condições de participação nas culturas do escrito: Pedro Nava e a formação na família. (19031913). Tese de Doutorado defendida junto ao Programa de Pós-Graduação em Educação, da Universidade Federal de Minas Gerais - UFMG, em 2008.

Disponível em: <http://www.bibliotecadigital.ufmg.br/dspace/handle/1843/FAEC-85FMPB>.
} 
Nesse caso, admitir-se-á, por “imagem literária”, o conhecimento construído sobre o objeto eleito, nas relações do indivíduo com o seu meio social, uma espécie de saber que diz alguma coisa sobre uma realidade experimentada. A manifestação de tal termo se dá por ocasião da visão de mundo do escritor, seu pertencimento a uma classe social, sua relação com os problemas de seu tempo e com os atores sociais.

A análise de tais textos permitiu a extração de "imagens literárias" sobre o percurso e o itinerário da experiência educacional no contexto da modernidade nacional. A relevância desse estudo está em apresentar, no campo histórico, o lugar reservado à escola, conforme as narrativas, no projeto de sociedade brasileira que se pretendia republicana.

\section{Uma prévia apreciação da escola no contexto histórico brasileiro}

As transformações econômicas, sociais e políticas ocorridas no Brasil a partir da segunda metade do século XIX teriam contribuído para algumas modificações na fisionomia do país, no mercado internacional. O deslocamento da primazia econômica das atividades agrícolas do norte para o eixo sul-sudeste, pela lavoura cafeeira, figurará como principal lastro na balança comercial nacional, por toda a segunda metade do século XIX. O desenvolvimento agrícola no Vale do Paraíba faria surgir uma nova classe aristocrata, constituída por fazendeiros do café.

O capital gerado pela exportação do café ${ }^{2}$, no entanto, foi considerado importante para o conjunto de transformações que o país experimentaria a partir da segunda metade do século XIX.

A modernidade tardia do país seria substanciada por uma remodelação material, pela expansão urbana, pela via de transportes ferroviários, pelas companhias de navegação a vapor, pelo telégrafo, pela incipiente atividade industrial, pelo trabalho assalariado, pelo transporte urbano e pelo surgimento de rede bancária (PRADO JUNIOR, 1974, p.157).

\footnotetext{
${ }^{2}$ Cf. HOLANDA, S. B. Raízes do Brasil. S. Paulo: Cia das Letras, 1995. O termômetro dessa transformação pode ser avaliado pelos números decorrentes das exportações. Até 1850 , as cifras nunca passaram de 60 mil contos por ano. No exercício de 1951, alcançam 76 918:000\$000 e, no ano seguinte, 92 860:000\$000 (p. 77).
} 
Paradoxal ao progresso registrado na economia brasileira, a expansão da escola elementar não correspondeu a um projeto republicano. Estudos desenvolvidos por Moacyr (1937), Almeida (1989), bem como por estudiosos (as) contemporâneos (as) a exemplo de Romanelli (1999), Faria Filho (2000), Vidal (2005), Marcílio (2005), Sousa (2008), Veiga (2007), Saviani (2008) dentre outros(as), apontam contradições profundas no nosso sistema de ensino, demarcado pelos altos índices de analfabetismo da população em idade escolar ${ }^{3}$, tanto na segunda metade do século XIX, quanto nas primeiras décadas após a proclamação da República.

Tal fato colocava o país na contramão da história, tendo em vista que, dentre as fontes que nutriam o debate educacional no século XIX, destacavam-se aquelas que enalteciam a relação intrínseca entre a educação e a aquisição do conhecimento em instituições formais (BURKE, 2003, p. 72) e as que defendiam a escolarização das massas como atributo indispensável aos fundamentos da sociedade industrial (SOUSA, 2008, p. 20).

O adendo constitucional de 12 de agosto de $1834^{4}$, conhecido por Ato Adicional, acentuaria as disparidades educacionais entre as unidades federativas. A crítica ordenada ao referido adendo constitucional, feita pelo educador Fernando de Azevedo (1963), ressaltaria a gênese histórica do caráter dualista do sistema educacional brasileiro.

As publicações das referidas obras de ficção da literatura nacional, em destaque nesse estudo, aconteceram com uma distância de quase quatro décadas de uma para outra. Porém, ambas trazem em comum algumas "imagens literárias" sobre a escola que denunciavam um modelo educacional que parecia congelado no tempo, sem nenhuma articulação com o debate em torno do progresso nacional.

Vale ressaltar que no contexto histórico em que o romance Casa de Pensão fora publicado, na década de 1880, a realidade educacional brasileira se orientava pela reforma de ensino Leôncio de Carvalho 5 . Quanto ao cenário social de publicação da

\footnotetext{
${ }^{3}$ LOURENÇO FILHO, M. B. Redução das taxas de analfabetismo no Brasil entre 1900 e 1960: descrição e análise. Revista Brasileira de Estudos Pedagógicos - RBEP, Vol. XLIV, Out / Nov, n. 100, 1965. P.250-272. Disponível em:<http://portal.inep.gov.br/acervo-pesquisa-lourenco>. Acesso: 15/09/2015.

${ }^{4}$ Lei de $\mathrm{n}^{\circ} 16,12$ de agosto de 1834 , que rezava no artigo $10^{\circ}$, parágrafo $2^{\circ}$, as Assembleias Provinciais ficavam obrigadas a prover a instrução de primeiras letras e o Curso de Humanidades. Disponível em: <http://www.planalto.gov.br/ccivil_03/leis/LIM/LIM16.htm>. Acesso em 15/09/2015.

${ }^{5}$ Decreto ${ }^{\circ} 7247$, de 19 de abril de 1879 . Reforma o ensino primário e secundário no município da Corte e o
} 
coletânea Os Bruzudangas, na década de 1920, sem desmerecer a inovação estética da semana de Arte Moderna, que dentre as bandeiras de luta destacava a de reinventar o país, (MARCÍLIO, 2005, p. 115), destaca-se a criação da Associação Brasileira de Educação ABE (SAVIANI, 2008, p. 229), que viria a promover as conferências nacionais de educação e a empreender reformas de instrução pública pelo país. ${ }^{6}$ Ambas as reformas guardavam uma preocupação em comum: a atenção pedagógica à educação primária. Se a reforma Leôncio de Carvalho instituíra o Método de Lição das Coisas, em substituição ao método de ensino mútuo, reforçando ser o método na prática do ensino uma questão pedagógica central da escola primária, (MARCILIO, 2005, p. 130), as reformas educacionais dos educadores liberais, profundamente influenciadas pela filosofia educacional do norteamericano John Dewey (1859-1952), em torno do movimento escola nova, caracterizaramse como decorrentes de movimentos políticos, educacionais e pedagógicos organizados pelos profissionais de ensino, congregados na $A B E$, de critica e de enfrentamento da educação nacional, a enfatizar a dimensão política, pedagógica e técnica da escola primária, cobrando a responsabilidade republicana dos poderes públicos para com a população em idade escolar, por via de algumas reformas educacionais propostas aos governos estaduais. (SAVIANI, 2008, p. 136-140).

Uma vez que as "imagens literárias" sobre a sala de aula, contidas em tais narrativas, apontam um modelo educacional nacional atrasado no tempo, demarcado pelo dualismo pedagógico sinalizado por Azevedo (1963), a realidade escolar tenderia a ser bem mais complexa, pois sobranceiro era o descompasso entre o institucional, aquilo que as reformas anunciavam, e o instituído, a prática do ensino na rotina intraescolar, pelos rincões brasileiros.

Pelo visto, o debate educacional que vinha sendo descortinado desde o último quartel do século XIX não surtiria efeito prático no mundo da sala de aula ao serem cruzadas com as visões sobre a escola presentes em ambas as obras.

superior em todo o Império. Disponível em:<http://www2.camara.leg.br/legin/fed/decret/1824-1899/decreto7247-19-abril-1879-547933-publicacaooriginal-62862-pe.html>. Acesso em: 14/09/2015.

${ }^{6}$ A primeira Conferência Nacional de Educação foi organizada pela ABE em 1927. No intervalo de 1920 a 1930 são verificadas as seguintes reformas estaduais de ensino: no Ceará, por Lourenço Filho em 1922; no Paraná, por Lysimico Ferreira da Costa e Pietro Martines em 1923; no Rio Grande do Norte, por José Augusto em 1924; na Bahia, por Anísio Teixeira em 1925; em Minas Gerais, por Francisco Campos e Mario Cassanta em 1927; no Rio de Janeiro, por Fernando de Azevedo em 1928; em Pernambuco, por Carneiro Leão em 1929 (SAVIANI, 2008, p. 177). 


\section{Uma breve apreciação sobre o uso da literatura ficcional como fonte na}

pesquisa histórica

Dentre as diversas fontes utilizadas pela história da educação para análise de fenômenos educativos se destaca a literatura de ficção. Trabalhos desenvolvidos por investigadores que se utilizam deste conhecimento como fonte de pesquisa têm dado uma significativa contribuição à história da educação brasileira, pois, tanto a história quanto a literatura se fundam em processos de socialização de memórias, de narrações e de discursos (LEMAIRE, 2000, p. 12).

A memória é do passado, parafraseando um aforismo aristotélico (RICOEUR 2007, p. 34). E entender a história só é possível quando se pressupõe a existência do passado. $O$ fato de escrever histórias é a prova da possibilidade de se tentar conhecê-lo (WHITE, 1994 p. 21). Sem pretender cair em aforismo ao estender a discussão à luz do debate da teoria da história, a discussão que aqui se acrescenta apenas vai ao encontro para demonstrar, com base nas leituras subjacentes, que, no ato da escrita da literatura de ficção, as reminiscências do autor transportam ao presente dados do passado. Na narrativa ficcional, as "imagens literárias" são frutos da visão de mundo do escritor, sujeito que participa da experiência social. Olhando por tal prisma, Rocha e Pinto Neto (2012, p. 36) reforçam tal argumento ao deduzirem que na recorrência à memória, por um determinado indivíduo, em busca de sentido para suas experiências vivenciadas, vêm à tona imagens, sons, cenas e personagens como partes integrantes de tais vivências, em algum momento do passado. Com base em tal entendimento, a literatura ficcional brasileira produzida nos séculos XIX e XX ocupa lugar privilegiado ao se pretender representar as experiências escolares. A representação sobre a escola, encontrada na narrativa de alguns textos, possibilita múltiplos sentidos que favorecem a compreensão sobre para onde apontava a nossa política de educação (ROCHA e PINTO NETO, 2012, p. 37).

O debate sobre o uso de fontes literárias na pesquisa histórica não é recente. Da década de 1970 para cá, o diálogo entre historiadores e estudiosos da literatura teria se consolidado no cenário da pesquisa social, assim destaca Chiappini (2000). Ao se destacar uma compreensão sobre o interesse por aquilo que os textos literários são capazes de contribuir com a pesquisa historiográfica, partindo-se das proposições da referida 
pesquisadora, admite-se tal interesse associado à valorização dos testemunhos capazes de ressignificar o passado. O uso de textos ficcionais na pesquisa histórica acrescenta, mas não deve ser tomado com o mesmo critério de análise de outras fontes tais como militares ou políticas. Isso devido ao campo literário trazer registros de sujeitos anônimos na história. Ao se tomar cuidado com tal critério, a autora reforça o aforismo de que no uso da literatura ficcional, como fonte historiográfica, deve ser posta em questionamento a própria noção de "fato histórico", pois ela precisa ser posta em discussão, haja vista que a narrativa ficcional encerra em si o "registro dos afetos", cujo trabalho investigativo corre atrás de vestígios de sensibilidade que representam nuances do cotidiano de sujeitos no anonimato (CHIAPPINI, 2000, p. 19).

A pesquisa histórica, ao trabalhar com outras linguagens, em particular subjacente à literatura de ficção, enaltece os elementos constitutivos da realidade social. A literatura ficcional, entendida como campo disciplinar, tende a expressar, por meio de imagens, as relações sociais, na medida em que contribui para modelação das formas de agir e de pensar, ao oferecer uma avaliação do real problematizado. (VIEIRA et al.,1991, p. 21).

Uma discussão pertinente, nesse debate, diz respeito à questão dos limites que separam a história da literatura de ficção. No ato do trabalho investigativo, o pesquisador em história se depara com a instabilidade das fronteiras, uma vez que a narrativa ficcional oferece-lhe literalidade. Nesse sentido, tanto a história quanto a literatura podem ser tomadas como campos disciplinares abertos (CAMILOTTI e NAXARA, 2009, p. 17).

Ao partir das inferências aristotélicas, Pesavento (2001) considera que tanto a história como a ficção devem ser consideradas narrativas. Como tal, a narrativa histórica estaria associada ao mundo pretérito, ao passo que a ficção corresponderia a algo que poderia ter acontecido. Ao considerar tal argumento, a referida autora reforça a proposição da narrativa histórica como verdadeira, não significando considerá-la como mimese dos fatos acontecidos. Assim como na ficção, na construção historiadora há a presença do narrador, isto é, aquele que vai mediar o fato acontecido a uma situação não presenciada. Nesse sentido, a história, enquanto voz narrativa, é controlada pelo historiador, "viajante do tempo", embora submetida aos rigores do método das ciências sociais. É o sujeito que organiza e ordena o acontecido e o apresenta ao público 
interessado por meio de uma relação estabelecida com o objeto (PESAVENTO, 2001, p. 34).

Com isso, o diálogo da história com a literatura ficcional vai diluindo fronteiras e abrindo portas à interdisciplinaridade. Contudo, historiador, romancista e leitor se encontram fora do acontecido. O romancista, por sua vez, resgata sentimentos e visões das classes e etnias que tiveram suas vozes silenciadas, recriando ficcionalmente a "angústia de um sujeito histórico". A história penetra a "essencialidade dos fenômenos", transfigurado pela ficção (MAESTRI, 2012, p. 42). A atividade intelectual vai permitir “recriar a ambiência" com coerência e dotada de significados. Em nome do "efeito real", pela estrada sinuosa da imaginação, leva a representar outro contexto (PESAVENTO, 2001, p. 40). Não à toa, o processo de representação do real, proposto pela história, envolve "criação, invenção, opções, estratégias de conhecimento" (PESAVENTO, 2001, p. 41) ao passado pensado, aproximando-se do real.

Tanto a história quanto a literatura ficcional, tomadas como narrativas que expõem pontos de vistas, são discursos que falam sobre o mundo. Corroborando com a discussão, Lemaire (2000) aponta que, devido ao questionamento epistemológico circunscrito em dois níveis distintos de entendimento, são estabelecidos os laços que unem o discurso histórico ao literário. Tais laços podem ser compreendidos, segundo ela, em duas bases: uma que estabelece uma distinção entre o passado real e a historiografia, demarcada pela "passeidade", isto é, o discurso construído pelo historiador; e outra que encerra a convicção de serem os dados do passado representações de fatos ocorridos. Os dois pressupostos permitem que seja ultrapassada a fronteira convencional entre a verdade, enquanto reconfiguração autorizada do passado, sob os critérios e exigências científicas, e o verossímil, isto é, o plausível, situado entre o verídico e o falso, mas capaz de dizer o fato imaginado (LEMAIRE, 2000, p. 10).

A comparação entre a história e a literatura estabelece uma diferença apenas na questão metodológica. A história, como narrativa autorizada, torna-se autoritária porque baseia seu estatuto científico na legitimação das fontes e na preocupação da investigação sobre documentos, conforme exigências do método de investigação na pesquisa social. A literatura de ficção é livre. É permitido ao criador que o imaginário "levante voo", que 
fuja, numa certa medida, aos condicionantes impostos pela exigência de verificação pelas fontes (LEMAIRE, 2000, p. 11).

Neste cotejo, ao investigador da história da educação, por exemplo, cabe a apropriação de "concepções sociais correntes da cultura e educação", pois, embora os textos ficcionais tenham sido produzidos em décadas anteriores, carregam “cristalizações interpretativas”, sustentadas em conceitos simplificados no campo antropológico e sociológico (XAVIER, 2008, p. 21).

Ao ser problematizado o poder da literatura de ficção como peça importante para compreensão de uma determinada realidade, mesmo que por meio de uma linguagem figurada, Roland Barthes destaca que toda a obra literária está povoada por ciências, tendo em vista o escritor emanar seu potencial criativo das condições objetivas da sociedade na qual está inserido. Segundo destaca, a literatura é, antes de tudo, uma convenção. Reserva-se ao texto literário o direito de suavizar a “ditadura da língua”. Enquanto sopro que escapa das amarras das estruturas de poder, o texto ficcional representa o real em palavras, por mais imagético que seja produzido. A literatura permite a criação de novos universos, essa elaboração tem como base a realidade da qual o escritor faz parte. (BARTHES, 2000, p. 22).

Ao fazer uso de romances na pesquisa histórica, Pinto Neto (2001) acrescenta ao debate a categoria atribuída ao referido gênero por lan Watt (1996), como "imitação da vida". Não como reflexo da realidade, mas uma recriação que permite aos leitores se reportarem ao universo da narrativa, ao ponto de tomá-la como modelo para repensar sua experiência social. (PINTO NETO, 2001, p. 44). Devido a tal fato, o referido autor destacaria a importância de tal gênero literário ter alcançado, na era moderna, significância na captação de leitores e no centro de interesse de pesquisadores em história.

Nesse sentido, no século XIX, o romance ganhou poder sobre a experiência privada fazendo frente às influências e aspirações da consciência moderna. Em tal gênero não haveria dificuldades de inserção do público leitor à obra (PINTO NETO, 2001, p. 38). Como modelo de se pensar o mundo, as "imagens literárias" traduzem uma variedade de aspectos da vida social, cabendo ao investigador identificar aquilo que convier aos objetivos de uma determinada investigação. (ROCHA e PINTO NETO, 2012, p. 36). 
No caso em apreço, na pesquisa historiográfica, os romances não devem ser tomados como documento, embora retratem uma realidade objetiva; mas como construções que representam uma realidade social. As "imagens literárias" destacadas nas obras ficcionais em estudo se reportam às experiências escolares no Brasil, na passagem do Império para a primeira fase da República.

\section{O gênero romance e a representação da escola brasileira na passagem do século XIX ao século XX}

O uso do gênero romance, por exemplo, como fonte atraente para a intenção historiadora, em particular em educação, exige atenção do investigador ao transitar num território imagético-discursivo, rabiscado de imagens e de cores, cujas "palavras em festas" induzem a uma construção intelectual movida pelas forças subjetivas que movimentam a produção literária. (BARTHES, 2000, p. 22).

Seguindo tal assertiva, o romancista, ao contrário do historiador que conduz sua intenção presa à lógica da veracidade dos fatos, é livre para criar sua história ao ser movido por forças que não se prendem ao método científico (BARTHES, 2000, p. 18).

Nesse sentido, o verossímil, contido na obra de ficção, representa uma visão de mundo, elaborada a partir de esquemas mentais do escritor. A produção literária deixa rastros, imagens, experiências sociais e ambientes culturais que podem ser perseguidos pelos historiadores na tentativa de ressignificar, por meio das representações, o passado. Reconstruir o vivido, tomando a narrativa ficcional como fonte, é buscar encontrar a espiral da temporalidade, possível de ser atingida somente pela potencialidade criadora. (PESAVENTO, 2001, p. 41).

Ao tomar um romance como fonte na pesquisa em história da educação, por exemplo, é preciso devotar atenção às relações de semelhanças e diferenças presentes no texto, por denunciarem momentos de tensão entre o percebido e o imaginado pelo escritor. Vale ressaltar que, para Bakthin et al (1993, p. 135), a principal marca do romance é a palavra que o homem fala. Desse modo, o sujeito é marcado pelo tempo em que vive, constituindo-se, portanto, um ser histórico-social por natureza. 
Os romances brasileiros produzidos no século XIX e início do século XX são considerados fontes importantíssimas para a nossa história. Assim destaca Pinto Neto (2001), ao fazer uso, em estudo, de algumas obras ficcionais, do período acima destacado, em busca de representações sobre a ciência no Brasil.

O conjunto das transformações que o país experimentava naquele contexto está representado nas obras literárias, tomadas como fonte nesse estudo. Eis a riqueza do material analisado nesta pesquisa. Nessa compreensão, perseguiram-se, nos textos tomados em estudo, as "imagens literárias" que se sobressaem como experiência escolar de determinados personagens.

No século XIX prenunciou, seguindo a tradição histórica estabelecida pelo escritor Júlio Verne (1828-1905), com o escritor francês Émile Zola (1840-1902) ${ }^{7}$, considerado o representante primaz do movimento estético do "naturalismo", o escopo de um modelo de literatura ficcional engajada, denominado por "literatura de emancipação", influenciado pelos princípios das ciências experimentais (PINTO NETO, 2001, p. 25).

No caso brasileiro, influenciado pelas ideias seculares, segundo aponta o referido estudo, desde a segunda metade do século XIX que os romancistas aportavam no movimento estético do "naturalismo" ${ }^{\text {. }}$ Participando desse novo frenesi cultural, uma maciça gama de impressos, não restrita aos romances, fará circular pelo país jornais e livros, trazendo, em seu bojo, a divulgação das ideias científicas da época. Tratava-se de uma literatura de divulgação que se comportava em trazer ao grande público os discursos das ciências biológicas e sociais frente às contradições da sociedade (PINTO NETO, 2001, p. 41), que corria para alcançar o trem da modernidade embalado nos trilhos do progresso.

Uma leitura de dois textos de ficção, consagrados na literatura brasileira, o romance Casa de pensão, de Aluísio Azevedo (1857-1913) e o livro Os Bruzudangas, ${ }^{9}$ de Lima Barreto (1881-1922), permite deduzir que ambos têm, em comum, a preocupação em

\footnotetext{
7 É atribuída à publicação da obra Germinal, de Émile Zola (1840-1902), em 1870, na França, marco inicial do movimento estético Naturalismo. Fonte: <http://www.infoescola.com/literatura/naturalismo/>.

${ }^{8}$ Com o romance $O$ Mulato, publicado em 1881, Aluísio de Azevedo passa a ser considerado o principal representante do Naturalismo no Brasil. Disponível em: <http://www.infoescola.com/livros/o-mulato>. Acesso 14/08/2015.

${ }^{9} \mathrm{Cf}$. BOSI, Alfredo. A literatura brasileira. O pré-modernismo. São Paulo: Cultrix, 1966. É considerado um autor pré-modernista. O termo Pré-Modernismo é atribuído a Tristão de Ataíde para designar o período cultural brasileiro transitório entre o início do século XX e a Semana de Arte Moderna de 1922 (p. 11).
} 
representar a educação brasileira do século XIX e início do século XX, principalmente no tocante à rotina pedagógica da escola, numa tentativa de puxar ao debate nacional a necessidade de mudanças políticas. Aquelas “imagens literárias” induzem as aspirações sociais de segmentos que associavam, ao progresso, o acesso da população à escolaridade básica.

\section{“Imagens literárias" da escola no romance Casa de Pensão}

O livro está inserido na corrente estética do Naturalismo. Nele está presente a tendência documental e experimental característica do romance naturalista. O autor deixa de lado o sentimentalismo e a evasão ao buscar ressignificar a realidade objetiva.

Segundo uma avaliação de Antonio Candido (2003, p. 390), o escritor carioca Lima Barreto considerava importante o desvendamento das problemáticas sociais por meio da literatura. Para ele, a literatura devia ter alguns requisitos indispensáveis. Antes de tudo, ser sincera, isto é, transmitir diretamente o sentimento e as ideias do escritor da maneira mais clara e simples possível. Devia também dar destaque aos problemas humanos, em geral, e aos sociais, em particular, focalizando os que são fermento de drama, desajustamento, incompreensão. Isto porque, no seu modo de entender, a literatura tem a missão de contribuir para libertar o homem e melhorar a sua convivência.

É assim que, em Casa de Pensão, o Naturalismo está fortemente marcado desde o início do romance, quando o protagonista surge "fatalisticamente" desajustado pela escola e pela família, representando, desse modo, as relações e os momentos de tensões sociais do período.

No enredo, o personagem Amâncio inicia sua peregrinação na cidade da Corte, aonde fora enviado, pelo pai, um comerciante radicado no Maranhão, após a conclusão do Liceu provincial para prosseguimento nos estudos. A ordem é ingressar na Academia de Medicina do Rio de Janeiro, para de lá se fazer doutor. “(...) Não se trata aqui de fazer um 'médico', trata-se de fazer um 'doutor' [...]”' (AZEVEDO, 1989, p. 22). Esse trecho retrata bem a mentalidade burguesa e aristocrática da época. O jovem não buscava uma profissão, mas sim um diploma, um título de doutor, ainda que não possuísse grande conhecimento intelectual que o fizesse merecer a titulação. 
Na medida em que a trama vai se desenrolando, o personagem, em processo de reminiscência, vai trazendo à narrativa alguns recortes de sua trajetória escolar. É precisamente isso o que interessa neste estudo. Com base em tais imagens, torna-se possível uma aproximação do que poderia ter sido a realidade pedagógica e política da escola primária numa cidade do sertão brasileiro, no final do século XIX.

Aos sete anos entraria para a escola primária. "Que horror!". Eis a expressão contida no texto. O mestre, tal de Pires, aos olhos das crianças era um homem "grosseiro", "bruto", de "cabelo duro" e "olhos de touro". Batia nos alunos por gosto. Talvez um mau hábito do ofício de ensinar meninos. Na aula só falava a berrar, como se “dirigisse uma boiada". Na descrição do autor, era um "homem que tinha as mãos grossas", sempre a falar com uma voz áspera e de “catadura selvagem”. "Quando metia para dentro umas poucas mais de vinho", seu comportamento ficava pior (AZEVEDO, 1989, p. 16).

A quem estava entregue a educação das crianças do Brasil, no último quartel do século XIX? Quando a Europa e os Estados Unidos da América, sinalizados como civilizações avançadas, socializavam ideias e experiências pedagógicas com outros países, dado que havia evidência de alguns dos nossos intelectuais e políticos ${ }^{10}$, movidos por diletantismo, terem acesso àquele conjunto de leituras no seu original, oriundas da pedagogia moderna, a educação elementar das crianças pelo território nacional estava entregue a mestre de ensino desprovido de uma devida formação didática. Pelo depoimento acima, a aversão das crianças à sala de aula era pertinente. A sala de aula foi transformada, de acordo com o relato do personagem, muito mais num ambiente de tortura do que de aprendizagem.

O personagem Pires, mestre de ensino de primeiras letras que alfabetizava aquelas crianças numa cidade do interior da província do Maranhão era a representação dos professores leigos brasileiros. Sob o olhar extraído da narrativa ficcional, aquele personagem era visto como "o carrasco, o tirano, o inimigo e não o mestre" (AZEVEDO, 1989, p. 08), instigando a reflexão sobre a situação docente e o itinerário da escola que estava entregue aos caprichos de mestres que não tinham a devida formação

\footnotetext{
${ }^{10}$ É o caso de Rui Barbosa (1849-1923), que fora o relator da Comissão de Instrução Primária, de 1882. Uma de suas façanhas foi a tradução do livro do norte-americano Norman Allison Calkins (1822-1885), intitulado Primeiras Lições das Coisas, publicado no Rio de Janeiro em 1896. (SAVIANI, 2008, p. 167).
} 
pedagógica. Era o apanágio do descaso político que não tinha a educação como prioridade nacional.

E no conceito dos pais, representantes da sociedade escravista, a figura do mestre carrasco era positiva. Nele, enxergavam a figura que alfabetizava e disciplinava os filhos com zelo. A fala do personagem Amâncio apontava a matiz da ignorância dos pais. Um verdadeiro paradoxo, o qual estava em voga nas matrizes da pedagogia moderna, que orientavam a prática escolar nas sociedades mais avançadas. "Os Pais ignorantes, viciados pelos costumes bárbaros do Brasil, atrofiados pelo hábito de lidar com escravos, entendiam que aquele animal era o único professor capaz de 'endireitar os filhos"” (AZEVEDO, 1989, p. 08).

Pelo recorte, a escola estava inserida num modelo de sociedade fechada, guiada pelo poder da autoridade e das tradições. Por ter sua economia atrelada à mão de obra escrava, era intolerante a tudo aquilo que fosse entendido como rebeldia, mesmo que fosse a manifestação de um espírito curioso que se rebelasse contra o estado de coisas, por meio de suposta indisciplina.

Outra passagem na narrativa chama a atenção do leitor. Um dia pela manhã, no início de uma aula, o mestre Pires o pegou mais seriamente. Na ocasião, Amâncio estava com oito anos de idade. Ao adentrar à sala de aula, os alunos, imediatamente, tomaram às pressas os seus competentes lugares. Como de praxe, o silêncio como sinal de profundo respeito à presença do professor em sala de aula. Imediatamente, em um só coro, os meninos começaram a estudar a lição em voz alta. Tudo correria na sua rotina didática quando, de repente, ouviu-se um estalo de uma bofetada em alguém. A desconcentração causou um rumor na turma. Impacientando-se com o ocorrido, o mestre levantou os olhos impiedosamente sobre a classe, tocou uma campainha que se posicionava sobre a mesa e fitou o olhar nos olhos assustados de Amâncio.

(...) - Sr. Vasconcelos! - gritou o mestre - porque espancou o senhor aquele menino? Amâncio respondera humildemente que o menino insultara sua mãe.

- É mentira! Protestou o novo acusado.

- Que disse ele? Perguntou o Pires.

Amâncio repetiu o insulto que recebera. Toda a escola rebentou em gargalhada. 
- Cale-se, atrevido! Berrou o professor encolerizado, a tocar a campainha - Mariola! Dizer tal coisa em pleno recinto da aula!

$\mathrm{E}$, puxando a pura força o delinquente para junto de si, ferrou-lhe meia dúzia depalmatoadas.

Amâncio, logo que se viu livre, fez um gesto de raiva.

- Ah! Ele é isso?! Exclamou o professor - Tens gênio, tratante?! Ora espera! Isso tira-se!

E, voltando-se para o rapazito que levou a bofetada, entregou-lhe a férula e disse-lhe que aplicasse outras tantas palmatoadas em Amâncio.

(AZEVEDO, 1989, p. 10)

Que tipo de efeito supostamente pedagógico tal ato surtiria, dali para frente, na conduta daquele aluno, no contexto escolar e na vida pessoal? A cena exposta denuncia um efeito nefasto na vida do indivíduo, mas suficientemente importante na manutenção da ordem em sala de aula: "Ficou medroso e descarado. No fim de algum tempo já podiam, na escola, insultar a mãe quantas vezes quisessem, que ele não se abalaria" (AZEVEDO, 1989, p. 10).

Como se observa no recorte acima, parecia ser uma coisa natural a punição de crianças na rotina escolar. ${ }^{11} T a l$ prática colaborava com a inibição de iniciativas individuais dos alunos, na maioria das vezes confundidas com indisciplina, uma prática "pedagógica” não oficial, mas corriqueira, que se arrastou pelo cotidiano escolar brasileiro até meados da década de 1960, pela fragilidade política de fiscalização do ensino nacional, cuja origem remonta à Sociedade dos Irmãos das Escolas Cristãs, na Pedagogia de Jean Baptiste La Salle (1651-1719), na Europa do século XVII. Segundo Larroyo (1970, p. 461), ao criar o referido instituto, La Salle redigiu um código de castigos e recompensas. A disciplina era classifica de duas maneiras: preventiva e repressiva. Na segunda, a correção corporal propunha punir os alunos pelas faltas cometidas. As crianças deviam ser corrigidas como seres racionais. Na correção corporal pesava o castigo físico.

A passagem no livro, vivida pelo personagem Amâncio, instiga a dedução da influência daquela pedagogia católica na educação das crianças nas províncias brasileiras. A descrição da prática do uso da palmatória, pelo mestre Pires, era indício da crença

\footnotetext{
${ }^{11}$ Cf. EBY, Friederick. História da educação moderna. Sec. XVI /sec. XX. Teoria, organização e práticas educacionais. Porto Alegre: Globo, 1978. Uma nova proposta de Pedagogia para educação das crianças sem o uso de castigos físicos estava sendo posta em voga no século XIX por Pestalozzi (1746-1827), no internato de Yverdun. Adepto de uma disciplina paternal, opunha-se à coerção e à punição por castigos físicos dos alunos. Defendia que a aprendizagem devia ser natural (p. 381).
} 
pedagógica de ser a correção corporal eficiente na manutenção da disciplina na sala, em favor do ensino e da aprendizagem.

O enredo do referido romance retratava o Brasil da segunda metade do século XIX e estava evidente a ingerência e a inoperância da fiscalização do ensino pelo poder público. Não surtira efeito, na vida prática da escola e das pessoas, o fim dos castigos corporais estabelecido pela Lei Geral, de 15 de outubro de $1827^{12}$, no seu artigo 15, a recomendar, apenas, os castigos cabíveis ao método de Lancaster. Como exemplo de outros mestres, o professor Pires era um leigo no exercício da docência. Carecia de uma devida formação para o magistério primário. Abusava dos castigos corporais nas crianças numa demonstração total de desconhecimento daquilo que a Pedagogia do século XIX, que vinha sendo tecida em alguns países da Europa e nos Estados Unidos da América, anunciava no processo de ensino-aprendizagem das crianças. ${ }^{13}$

O fato de o personagem Amâncio assumir uma nova atitude "medrosa e acanhada" na sala de aula, embora considerada, sob o olhar do mestre Pires e da família, como algo positivo, porque representava disciplina, na verdade era sinal de desdobramentos traumáticos.

Ao concluir as primeiras letras, Amâncio não se sentia um aluno eficiente nos estudos formais. Nutria a sensação de "não saber de nada", nas letras. Intuitivamente, sinalizava ter aprendido muito mais com os passeios de férias que fizera à fazenda de sua avó materna, no lugarejo de São Bento.

Esta passagem acima descrita puxa uma reflexão sobre a importância do contato da criança com a natureza, pela propriedade dada à observação como critério de aprendizagem. Se a imagem do mestre de ensino, Pires, se associava ao carrancismo didático, cuja prática se guiava cegamente presa ao modelo da lição de pura abstração, orientada pelo critério da repetição constante da lição, da aprendizagem de cor, da emulação e dos castigos físicos, é possível imaginar a contradição do modelo escolar que se perpetuava, pelos rincões brasileiros, dissociado do debate pedagógico moderno.

\footnotetext{
${ }^{12}$ Disponível em: <http://www.planalto.gov.br/ccivil_03/leis/LIM/LIM-15-10-1827.htm>. Acesso 14/09/2015.

${ }^{13} \mathrm{Cf}$. MORANDI, Franc. Introdução à Pedagogia. São Paulo: Ática, 2008. A pedagogia ganha escopo com a escola maternal, implantada no alvorecer do século XIX. O modo de transmissão do saber e as maneiras de "dar aula" serão levados em conta no funcionamento da instituição escolar (p. 45).
} 
Dentre o debate pedagógico da segunda metade do século XIX estava a proposta do método intuitivo, que orientava os mestres de ensino das crianças a aguçar a percepção antes das ideias, por meio da disciplina dos sentidos. A observação da natureza era o atributo que proporcionava a percepção e gerava o raciocínio, garantindo o conhecimento (VALDEMARIN, 2004, p. 107). Nesse caso, o fato de Amâncio intuir que aprendera muito mais nas férias porque tinha contato com a vida no campo. Tal passagem na obra sinaliza a apropriação do autor do debate pedagógica moderno, cujo método intuitivo na escola primária mostrava a importância da criança observar a natureza como processo de aprendizagem. Na prática prevalecia a escola tradicional. A aprendizagem da lição escrita, nos livros de ponto, era vista como mais significativa. Por isso, a certificação de aprovação plenamente em primeiras letras, desfechada numa solenidade pública, com a presença das autoridades constituídas da cidade, não representava muito para o personagem, porque (...) não sabia nada, quase que não sabia ler. Da gramática apenas Ihe ficaram “de cor algumas regras", sem que ele compreendesse patavina do que elas definiam (AZEVEDO, 1989, p. 12).

O personagem não demonstrava nenhuma "relação com o saber" ${ }^{14}$. O professor, muito mais preocupado com a disciplina corporal dos alunos, inábil no ato pedagógico, fragilizava o ato de ensinar a gramática e a matemática devido à prática conservadora.

\begin{abstract}
O Pires nunca explicava: - se o pequeno tinha a lição de memória, passava outra, e, se não tinha, dava-se algumas palmatoadas e dizia-lhe que trouxesse a mesma para o dia seguinte.

Mas, enfim, estava habilitado a entrar para o Lyceu, onde iria cursar as aulas de Francês e Geografia. (AZEVEDO, 1989, p. 13)
\end{abstract}

Enfim, com a conclusão do curso primário,o aluno estava habilitado a ingressar no Ginásio, no Liceu provincial. Uma nova etapa na vida escolar brasileira, para aqueles que tinham o privilégio de seguir nos estudos.

\footnotetext{
${ }^{14}$ Cf. CHARLOT, Bernard. Da relação com o saber: elementos para uma teoria. Porto Alegre: Artes Médicas, 2000. Apoiando-se na sociologia do sujeito, a referida teoria chama atenção para o saber aprendido com sentido e com prazer por parte do aluno. Para ilustrar a denúncia que o personagem Amâncio faz no romance, tal categoria foi tomada por empréstimo do referido pensador para legitimar e refletir o descompasso entre o que fora ensinado e o que não fora aprendido pelo mesmo. Eis a demonstração de um fracasso escolar (pp. 14-15).
} 
Edificados nas capitais das províncias brasileiras como espaços educacionais e pedagógicos delimitados, os Liceus nuclearam as cadeiras avulsas do Curso de Humanidades em um só ambiente, definindo um currículo único, a contemplar a formação do ensino pós-primário no Brasil.

Até a criação dos Liceus, acontecimento registrado na primeira metade do século XIX, o ensino das cadeiras de humanidades seguia pela oferta de aulas avulsas, à mercê de disponibilidades e de nomeações de lentes para determinadas cadeiras a serem ofertadas, tanto nas capitais, quanto nas principais cidades interioranas das províncias brasileiras. Os alunos corriam atrás das cadeiras. Ao serem edificados nas capitais das províncias brasileiras, como espaço educacional e pedagógico delimitado, os Liceus passaram a nuclear as cadeiras avulsas. O Curso de Humanidades ganhou uma nova organização, definindo o currículo e a seriação. A conclusão do referido nível habilitava o egresso às carreiras liberais (ANDRADE, 2011, p. 178).

A nucleação das cadeiras do Curso de Humanidades nos Liceus, mediante um currículo escolar edificado em um conjunto de disciplinas distribuído em séries, tenderia a ampliar o número de matrículas no ensino secundário, porque, supostamente, atenderia ao fluxo advindo das escolas primárias. No entanto, longe de supor que aquelas unidades de ensino agregassem toda a demanda do ensino primário das províncias, em particular, das capitais, o ingresso aos Liceus era restrito a um grupo seleto de alunos, mediante um severo processo chamado de exame de admissão.

O Lyceu, que bom! - oh! Ai não havia castigos, não havia pequenas misérias aterradoras da escola!

Não poderia faltar ás aulas, é certo! Mas, em todo o caso, estudaria quando bem entendesse e, lá uma vez por outra, havia de "fazer a sua parede". (AZEVEDO,1989, p. 13)

O ensino pós-primário levava a sensação de quem recebia uma carta de alforria do ensino elementar, pois, estava livre dos castigos corporais, reservados aos seus alunos. Muito mais importante do que o conhecimento que a escola secundária proporcionava, o entusiasmo do personagem se traduzia em sentimento de liberdade. "Estava livre, 
finalmente!". Livre para estudar e para decidir sobre sua conduta no ambiente escolar. Para escolher a carreira que lhe conviesse.

E a rotina do ensino secundário seguia com a matrícula por disciplinas: "Aos quatorze anos prestou exame de Francês e Geografia e matriculou-se nas aulas de Gramática Geral e Inglês" (AZEVEDO, 1989, p. 16).

Observa-se, pelo depoimento do personagem, que a organização curricular do ensino secundário, naquele contexto, estava pautada pela matrícula por disciplinas. Uma prerrogativa da Reforma Paulino de Sousa (1807-1866), de 1870, ao instituir os exames nas Províncias. ${ }^{15}$

A formação básica era composta por um conjunto de disciplinas que garantiam a preparação para os exames finais e a conclusão do curso de humanidades. De posse da certificação expedida pelos Liceus provinciais, que naquela época já gozavam da prerrogativa descentralizada de realização dos exames finais estabelecida pela orientação da reforma citada acima, os estudantes ficavam aptos a solicitar ingresso nas instituições de ensino superior. "Já eram válidos, felizmente, os exames do Lyceu do Maranhão e, com as cartas que daí houvesse, podia entrar nas academias da Côrte". (AZEVEDO, 1989, p. 27).

Anterior à reforma, a legislação estabelecia serem os exames preparatórios aplicados apenas na cidade da Corte ou naquelas províncias que tivessem cursos superiores. Agora, os exames podiam ser feitos na própria província, desde que houvesse uma Escola Normal e fosse respeitado o que reserva o referido decreto.

Concluindo o Liceu, o personagem Amâncio foi estimulado pelo seu pai, um abastado comerciante do Maranhão, para residir na cidade do Rio de Janeiro à cata de um curso superior. Tinha que se fazer doutor. E veio a estadia na cidade da Corte: "Afinal, graça aos esforços de Campos, conseguiu matricular-se na academia duas semanas depois de ter chegado ao Rio de Janeiro" (AZEVEDO, 1989, p. 20).

\footnotetext{
15 BASTOS, Geraldo Silva. A Educação secundária. Perspectivas históricas e teoria. São Paulo: Cia. Ed. Nacional, 1969. (p. 215)
} 
Ora, medicina! Medicina servia para algum moço pobre que precisasse viver de clínica; ele não estava n'essas circunstancias. Era rico! Só com o que lhe tocava por parte materna, podia passar o resto da vida sem se fatigar! ... Porque, pois, sofrer aquelas apoquentações do estudo? Porque razão havia de ficar preso aos livros, entre quatro paredes, quando dispunham de todos os elementos para lá fora, em liberdade, a se divertir e a gozar?! (AZEVEDO, 1989, p. 37-38)

Na passagem acima, é notória a visão que se fazia da educação superior naquele período. Os cursos superiores despertavam interesses daqueles jovens desprovidos de heranças e de fortunas que ambicionavam a ascensão social. O personagem demonstra um desapego ao curso de Medicina, pois tinha a convicção de que não precisaria do diploma para correr atrás de empregos públicos e nem de se instalar num consultório clínico para viver do atendimento de consultas aos ricos da sociedade.

\section{"Imagens literárias" da escola em Os Bruzudangas}

Na sequência desta análise, algumas crônicas extraídas do livro Os Bruzudangas vão tocar na mesma questão, quando apontam ser a educação superior, no século XIX e começo do século XX, no Brasil, a responsável pela construção de uma nobreza ambiciosa e aspirante à ascensão social, cujo diploma de nível superior funcionava como a chave que abriria todas as portas aos cargos públicos da burocracia do Estado. Assim, na obra, o Brasil vai se descobrindo como um país onde os interesses pessoais suplantam as necessidades e anseios da coletividade.

A sociedade brasileira tomou conhecimento de uma coletânea de crônicas intitulada Os Bruzudangas, publicadas no Rio de Janeiro no crepúsculo dos acontecimentos de 1922. Uma publicação póstuma que apresentava o espírito hilário de um escritor à frente do seu tempo.

Aquela coletânea representa uma sátira ao modelo social brasileiro do final do século XIX e início do século XX. O livro era um "retrato falado" de uma sociedade que almejava o píncaro da civilização, mas que esbarrava nas contradições históricas de sua herança colonial. Os comportamentos das pessoas, as visões de mundo, as tensões políticas, as ambições, as artimanhas, as barganhas, as etiquetas sociais, o espírito 
estético e a figura feminina, tudo simbolizava um universo social mergulhado num embate entre o profano e o sagrado, entre o moderno e o atraso, entre a civilização e a "barbárie", enfim, entre a cultura que representava o velho mundo e a luta do novo em copiá-la nos trópicos.

Dentre as terminologias criadas pelo escritor em tela, para caricaturar a elite intelectual, em particular a da capital da República, está a chamada nobreza doutoral. A “doutonomia”, expressão cunhada pelo próprio autor, era um fenômeno bem peculiar da sociedade brasileira. Originar-se-ia nas relações coloniais e se perpetuaria por todo o modelo de educação do período imperial. A aquisição de um certificado acadêmico, emitido pelas instituições de ensino superior, do período em destaque, representava um título nobiliário, simbolizando, no imaginário do portador e da sociedade que o reconhecia, o pertencimento a uma classe aristocrata. (XAVIER, 2008, p. 31).

Os bacharéis, formados pelas academias de ensino superior existentes na época, constituíam-se numa casta de intelectuais. O autor denominava tal casta de Nobreza Doutoral. É interessante observar, no final do livro a referência feita a tal categoria social, ao destacar uma ordem de valores atribuída aos cursos de nível superior, com destaque para Medicina, Direito e Engenharia.

O que representava ser doutor numa neófita República cujos $65,3 \%$ da população de 15 anos era analfabeta? (ROMNALLI, 1999, p. 62). Qual o sentido de um título de bacharel num estado dependente de uma economia de exportação, presa à grande propriedade rural e à monocultura? (PRADO Jr., 1974, p. 225). Uma República que não conseguia mexer na relação público e privado, herança do período colonial, cuja base patriarcal se apresentava como pedra no caminho do percurso de uma sociedade liberal moderna (HOLANDA, 1995, p. 145).

Segundo o referido escritor, uma "mitologia" em torno da figura do portador do título de bacharel fora consagrada pelas academias brasileiras. Qual era o sentido de um título acadêmico em tal circunstância? "O cidadão que se arma de um título em uma das escolas citadas, obtém privilégios especiais, alguns constantes das leis e outros consignados nos costumes" (BARRETO, [s.d], p. 18). 
Assim, ser doutor numa sociedade contraditória como a brasileira significava participar de privilégios assegurados para poucos, numa sociedade guiada por tradições, pelo poder da autoridade e pelos valores católicos.

A nobreza doutoral, satirizada na "República dos Bruzudangas", era assim descrita pelo citado cronista:

A nobreza da Bruzudanga se divide em dous grandes ramos. Talqualmente como na França de outros tempos, em que havia a nobreza de Toga e a da Espada, na Bruzudanga existe a nobreza doutoral e uma outra, por falta de nome mais adequado, eu chamarei de palpite.

A aristocracia doutoral é constituída pelos cidadãos formados nas escolas, chamadas superiores, que são as de medicina, as de direito e as de engenharia. (BARRETO, [s.d], p. 17)

E o povo? Quanto venerava os portadores daqueles diplomas?

O povo mesmo aceita esse estado de cousas e tem um respeito religioso pela sua nobreza de doutores. Uma pessoa da plebe nunca dirá que essa espécie de brâmane tem carta, diploma; dirá: tem pergaminho. (BARRETO, [s.d], p. 18)

Levando-se em consideração o descaso político para com a escola pública, alguém das camadas mais baixas da sociedade teria condição de acesso a tais cursos? "A formatura é dispendiosa e demorada, de modo que os pobres, inteiramente pobres, isto é, sem fortuna e relações, poucas vezes podem alcançá-la" (BARRETO, [s.d], p. 18).

E quanto aos cursos, formariam pessoas que atenderiam aos desafios reais da sociedade que se modernizava? "Em geral, apesar de serem lentos e demorados, os cursos são medíocres e não constituem para os aspirantes senão uma vigília de armas para serem armados cavaleiros" (BARRETO, [s.d], p. 18).

Excluindo-se o lado ficcional que a passagem do livro encerra e estabelecendo um paralelo com a realidade histórica da sociedade da época, a escola pública estava longe de cumprir sua função social. Conforme as matizes do texto em apreço, o curso acadêmico inspirava no candidato um título "nobiliárquico". 
E quanto ao jovem que almeja o ingresso numa academia, o que pensa sobre o curso superior? "O que mete medo aos candidatos à nobreza doutoral, não são os exames da escola superior; são os exames preliminares, aqueles das matrículas que constituem o nosso curso secundário" (BARRETO, [s.d], p. 18).

De acordo com o recorte acima, podem-se tecer algumas reflexões. Embora tal assunto não seja explorado nesta seção, deve-se o mérito de tal descentralização do ensino à referida Reforma Leôncio de Carvalho. Como está em destaque, os exames preparatórios ao ensino superior estavam inseridos dentro da própria rotina pedagógica do ensino secundário.

\section{Considerações finais}

Pelo que foi aqui brevemente exposto, é possível observar que, sendo a obra literária um objeto social, há nela muitas revelações acerca da sociedade de um tempo. 0 homem, enquanto ser essencialmente social e histórico, ao produzir arte, acaba por traduzir a forma de pensar e de agir de uma época, permitindo, desse modo, que a literatura constitua uma importante fonte para as pesquisas em Ciências Humanas e Sociais.

O romance Casa de Pensão, de Aluísio Azevedo e a coletânea Os Bruzudangas, do escritor carioca Lima Barreto, nos mostram importantes características da educação brasileira do século XIX e início do século XX, sobretudo no que se refere à dinâmica do cotidiano no ensino nos níveis elementar, secundário e superior, por meio da representação de experiências instrucionais e de anseios da sociedade de uma época.

As duas obras apresentam, ao leitor, a dinâmica pedagógica e as contradições do sistema escolar, que se esboçava à luz da legislação que vigorava. No bojo das contradições, ambos os autores apresentam, nos respectivos enredos, as formas como os alunos expressavam sentimentos em relação à escola como um todo, bem como as suas aspirações sociais, a partir do ingresso no ensino superior.

Desse modo, o que se nota é que, no final do século XIX e início do século $X X$, período representado pelas obras em estudo, a aprendizagem não é o foco da escola. Além disso, o poder da autoridade e a punição são grandes marcas educacionais, e o 
aluno se habilita para o ensino superior ainda que não tenha acumulado conhecimentos suficientes para tanto. Ademais, os dois autores trazem à tona uma importante reflexão em torno de um sistema de ensino frágil que, ligado à ingerência do poder público, não garantia a educação como direito, o que, em muito, se assemelha à atualidade.

\section{Referências}

ALMEIDA, José Ricardo Pires de. História da instrução pública no Brasil (1500-1889). São Paulo: EDUC; Brasília, DF: INEP/MEC, 1989.

ANDRADE, Francisco Ari de. A escola de costas para o sertão no romance Vidas Secas. In: SANTOS, Jean Mac Cole Tavares; ANDRADE, Francisco Ari de. (Org.) Ditos e interditos em educação brasileira. Curitiba: Ed. CRV, 2012. p. 37-44.

ANDRADE, Francisco Ari de. A escrita escolar de si e a memória do Liceu do Ceará contada por quem viveu. In: PINHEIRO, Antonio Carlos Ferreira; MADEIRA, Maria das Graças Loyola; CASTRO, Cesar Augusto; PADUA, Antonio de. Instituiçõos escolares e escolarização no Nordeste. João Pessoa: Ed. UFPB/Lapis e Papel; São Luis: EDUFMA, 2011.

AZEVEDO, Aluísio. Casa de pensão. São Paulo: Ática, 1989. Disponível em: http://www.bibvirt.futuro.usp.br. Acesso em 15 de junho/2015.

AZEVEDO, Fernando. A cultura brasileira: introdução ao estudo da cultura no Brasil. $4^{\mathrm{a}}$ ed., revista e ampliada. Brasília: Editora Universidade de Brasília, 1963. Parte III.

BAKTHIN, Mikhail; FORNONI, Aurora et al . Questões de literatura e de estética: a teoria do romance. $3^{\text {a }}$ ed. São Paulo: EDUSP, 1993.

BARRETO, Lima. Os Bruzudangas. [s.d]. Disponível em: <www.nead.unama.br >. Acesso em 15 de junho/2015. 
BARTHES. Roland. Aula. São Paulo: Cultrix, 2000.

BOSI, Alfred. A literatura brasileira. O pré-modernismo. São Paulo: Cultrix, 1966.

BURKE, Peter. A história social do conhecimento. De Gutemberg a Diderot. Rio de Janeiro: Jorge Zahar, 2003.

CAMILOTTI, Virgínia; NAXARA, Marcia Regina Capelari. História e literatura: fontes literárias na produção historiográfica recente no Brasil. Revista História: Questão \& Debate, Curitiba, n. 50, p.15-49, jan./jun., 2009. Disponível em:

<http://ojs.c3sl.ufpr.br/ojs/index.php/historia/article/viewFile/15670/10411>.Acesso em 08 de setembro/2015.

CANDIDO, Antonio. A educação pela noite e outros ensaios. São Paulo: Ática, 2003.

CHARLOT, Bernard. Da relação com o saber: elementos para uma teoria. Porto Alegre: Artes Médicas, 2000.

CHIAPPINI, Lígia. Literatura e história: notas sobre as relações entre os estudos literários e os estudos historiográficos. Revista Literatura e Sociedade, São Paulo, n.5,p.18-28, edição comemorativa, 2000. Disponível

em: <http://www.revistas.usp.br/ls/issue/view/30>. Acesso: 04 de setembro/2015.

COUTINHO, Afrânio. Conceito de literatura brasileira. Rio de Janeiro: INL, 1973.

EBY, Friederick. História da educação moderna. Sec. XVI /sec. XX. Teoria, organização e práticas educacionais. Porto Alegre: Globo, 1978.

FARIA FILHO, Luciano Mendes de; VIDAL, Diana Gonçalves. Os tempos e os espaços escolares no processo de institucionalização da escola primária no Brasil. Revista Brasileira de Educação. Rio de Janeiro, n. 14, p.19-34, maio/ago., 2000. Disponível em: <http://www.scielo.br/revistas/rbedu/paboutj.htm>. Acesso em: 08 de setembro/2015.

FREITAS, Anamaria Gonçalves Bueno de; SOUZA, Milena. Práticas de castigos escolares: enlaces históricos entre normas e cotidiano. Revista Conjectura, Caxias do Sul, v. 17, n.2, p. 17-36, maio/ago., 2012. Disponível em:

<http://www.ucs.br/etc/revistas/index.php/conjectura/article/view/>. Acesso em: 10 de julho/2015.

HOLANDA, Sérgio Buarque de. Raízes do Brasil. 26ª ed. São Paulo: Cia das Letras, 1995.

LARROYO, Francisco. História geral da pedagogia. Tomo I. São Paulo: Mestre Jou, 1970.

LEMAÍRE, Ria. O mundo feito texto. In: DECCA, Edgar Salvadori e LEMAÍRE, Ria. (Org.) Pelas margens: outros caminhos da história e da literatura. Campinas: Unicamp; Porto Alegre: URGS, 2000. p. 09-13. 
LOURENÇO FILHO, Manuel Bergstron. Redução das taxas de analfabetismo no Brasil entre 1900 e 1960: descrição e análise. Revista Brasileira de Estudos Pedagógicos RBEP, Vol. XLIV, Out / Nov, n. 100, 1965. P.250-272. Disponível em:<http://portal.inep.gov.br/acervo-pesquisa-lourenco>. Acesso: 15/09/2015.

MAESTRI, Mário. História e romance histórico: fronteiras. Novos Rumos, Marilia, SP, ano 17, n. 36, p. 38-44, 2002. Disponível em:

<www2.marília.unesp.br/revistas/índex.php/novosrumos>. Acesso em 04/09/2015.

MARCÍLIO, Maria Luiza. História da escola em São Paulo e no Brasil. São Paulo: Imprensa Oficial de SP; Inst. Fernand Braudel, 2005.

MELO, Juliana Ferreira de. Modos e condições de participação nas culturas do escrito: Pedro Nava e a formação na família. (1903-1913).Tese (Doutorado em Educação) Universidade Federal de Minas Gerais, Programa de Pós-Graduação em Educação. Belo Horizonte,-,2008. Disponível em:

<http://www.bibliotecadigital.ufmg.br/dspace/handle/1843/FAEC-85FMPB. Acesso: $14 / 09 / 2015$.

MOACYR, Primitivo. A instrução e o Império (subsídios para a história da educação no Brasil, 1854-1888). São Paulo: Nacional, 1937.

MORANDI, Franc. Introdução à Pedagogia. São Paulo: Ática, 2008.

MOSCOVI, Serge. A representação social da psicanálise. Rio de Janeiro: Zahar, 1978.

NAVA, Pedro. Baú de ossos. São Paulo: Ateliê/Giordano, 1999.

PESAVENTO, Sandra Jatahi. Fronteiras da ficção. Diálogos da história com a literatura. Revista História das Ideias, Coimbra, Pt, v. 21, 2000. Disponível em: <http://rhi.fl.uc.pt/vol/21>. Acesso em: 10 de julho/2015.

PILAR, Maria do Pilar de Araujo Vieira; PEIXOTO, Maria do Rosário da Cunha; KHOURY, Yara Maria Aun. A pesquisa em história. $2^{a}$ ed. São Paulo: Ática, 1991.

PINTO NETO, Pedro Cunha. Ciência, literatura e civilidade. Tese (Doutorado em Educação) - Universidade Estadual de Campinas, Programa de Pós-Graduação em Educação. Campinas, 2001. Disponível em:

<http://www.bibliotecadigital.unicamp.br/document/?code=vtls000217852>. Acesso: 08 de setembro/2015.

PRADO JUNIOR, Caio. História econômica do Brasil. $17^{\text {a }}$ ed. São Paulo: brasiliense, 1974.

RICOEUR, Paul. A memória, a história e o esquecimento. Campinas: Ed. Unicamp, 2007.

ROCHA, Heloisa Helena Pimenta e PINTO NETO, Pedro da Cunha. Dos temores ao encontro: o cotidiano escolar na literatura brasileira. Educação em Revista, Belo 
Horizonte, v. 28, n.01, p.35-60, 2012. Disponível em:

<http://www.scielo.br/pdf/edur/v28n1/a03v28n1.pdf>. Acesso em: 10 de julho/2015.

ROMANELLI, Otaíza de Oliveira. História da educação no Brasil. $22^{a}$ ed. Petrópolis, RJ: Vozes, 1999.

SAVIANI, Demerval. História das ideias pedagógicas no Brasil. São Paulo: Autores Associados, 2008.

SOUSA, Rosa Fátima de. História da organização do trabalho escolar e do currículo no século XX. (Ensino primário e secundário no Brasil). São Paulo: Cortez, 2008.

VALDEMARIN, Vera Tereza. Estudando as lições das coisas: análise dos fundamentos filosóficos do método de ensino intuitivo. Campinas, SP: Autores Associados, 2004.

VEIGA, CintyaGreive. História da educação. $2^{\text {a }}$ ed. São Paulo: Ática, 2007. VIDAL, Diana. Cultuas Escolares: estudo sobre práticas de leitura e escrita na escola pública primária (Brasil e França, final do século XIX). Campinas, SP: Autores Associados, 2005.

WHITE, Hayden. Teoria literária e escrito da história. Estudos Históricos. Rio de Janeiro, v.07, n. 13, p. 21-48, 1991, Disponível em:

<http://bibliotecadigital.fgv.br/ojs/index.php/reh/issue/view/279>. Acesso em o9 de setembro/2015.

XAVIER, Maria Elizabete Sampaio Prado. A educação na literatura do século XIX. Campinas: Alínea, 2008.

Recebido em: 16/07/2015 Aprovado em: 24/09/2015

Universidade do Estado de Santa Catarina - UDESC Programa de Pós-Graduação em Educação - PPGE Revista Linhas Volume 17 - Número 35 - Ano 2016 revistalinhas@gmail.com 